\title{
The Students' Comprehension In Analyzing English Text Of The Ma Darul Furqan Nw Mengkuru Graders
}

\author{
Mul Muliadi \\ mulmuliadi@nusantaraglobal.ac.id \\ Program Studi Pendidikan Bahasa Inggris Institut Pendidikan Nusantara Global
}

\begin{abstract}
This research is aimed to measure the students' compression in analyzing English text for the students of MA Darul Furqan NW Mengkuru. The students' comprehension in analyzing English text for the tenth year students of MA Darul Furqan NW Mengkuru are in average level. It can be seen from the mean score of the students that is 31.35 in which this number belongs average level. The percentages of successes of students' comprehension in analyzing English text for the tenth year students of MA Darul Furqan NW Mengkuru are low. After the scores were classified for the students' comprehension in analyzing English text, the researcher found 4 students who got very high score. It means that there were $13.33 \%$ of them were categorized very high level. Furthermore, there were 4 students who got high level; it means that there were $13.33 \%$ of students who were categorized high level. There were7 students who got sufficient level; it means that there were $23.33 \%$ of students who were categorized high level, and there were 15 students who got low level; it means that there were $50 \%$ of students who were categorized low level, moreover, there were none of students who got very.
\end{abstract}

Keywords: Comprehension, English Text.

\section{INTRODUCTION}

English as an international language is spoken in almost all over the world. It plays very important role in any aspects of international affairs. All countries in the world have their own language but English has been an international language in order to be able to interact among people all over the world. Indonesian chooses English as the first foreign language which is taught at almost all level of the school and it is studied as the compulsory subject in advanced education, whether in junior high school, even in elementary school.

The success of teaching learning process is always expected by teachers and students. The teachers want their students to master as much as possible what they have learned at the time. In this case, the teachers must be demanded to be more creative in the process of teaching and learning process. The teachers are always expected to help and guide their students in order to get the maximum capability and also the teacher can help improving and increasing the ability o the students, so that, they are able to master English well and intensively.

By learning English the students are expected to obtain knowledge or science when continuing their study at University. It is clear that English has been learned in the elementary school to university. Although the students have been learning since elementary school, it is still found that the students face many difficulties in analyzing English texts.

In the 2006 English the curriculum mention that teaching English relates to a goal of students at SMA/MA to process reading listening, and writing skills. In 2006 English curriculum, for senior high school (SMA/MA) the types of English texts are studying from the first class. The standard competence that is correlated by comprehending the kind of English texts is able to use spoken and written of English text. International or monologue in the correlation with English texts, with using schematic (generic) structure.

Furthermore, Hapsari (in cahyono 1997) states the problems found by the learner in analyzing of English texts are: genre of text, generic structure, and the character of text. The students' difficulties about character of text cause the difficulties in analyzing part of the text. Comprehension of English texts is really needed because students can differentiate which texts are used to express their ideas appropriately. Analyzing English text should be 
taught to students in order to know all kinds of text when they speak, listen, read and write.

Finally, students' comprehension in analyzing English text not be neglected, it is prominent role in order they can analyze English text.

Furthermore, the researcher investigates the students' comprehension in analyzing English text for the tenth year students of MA. Darul Furqan NW Mengkuru.

Scope and Limitation of Study

The study is merely included about subject of the study.

The subject of the study is the tenth year students of MA. Darul Furqan NW Mengkuru. The object of the study is limited on students' comprehension in analyzing English text.

Statement of the Problem

From the above statement, the writer formulates the statement of the problems; To what extent is the students' comprehension in analyzing an English text for students of $M A$. Darul Furqan NW Mengkuru; To what extent is the percentage of students' comprehension in analyzing an English text for the students of $M A$. Darul Furqan NW Mengkuru.

Objective of the study

This is merely intended to know:

The students' compression in analyzing English text for the students of $M A$ Darul Furqan NW Mengkuru; and the percentage of students' compression in analyzing an English text or the students of $M A$. Darul Furqan NW Mengkuru.

Significance o the Study

The result of some uses either theoretically or practically.

1) Theoretically

a. The result of this study is expected to be able to add a reference to the students in compression English text.

b. Give some contributions for developing students' ability in comprehending English text.

2) Practically

a. The result of this study is expected to be able to apply the appropriate methods for English teacher in teaching English texts.

b. The result of this study is expected to give some uses for English teacher in teaching English text.

2. REVIEW OF RELATED LITERATURE

\section{The Nature of Language Teaching}

Language is a system of arbitrary conventionalized vocal, written, or gesture symbol that enable members of a given community to communicate intelligibly with one another; while teaching is process of showing or helping someone to learn, giving instructions, guiding in the study of something in order to be able know and understand about certain knowledge (Brown, 2003).

According to Anthony (in Brown, 1994) that method is an overall plan for orderly presentation of language, material, no part of which is based upon, the selected approach.

Teaching is an activity carried out by teacher who specifies the goals, selects and carried out by teacher who specifies the goals, selects and arranges the materials, present them to learners and evaluate his performance by a short of the test to find out whether it successes or not. In this way, the teacher should use a good approach, method, technique, and organize the materials in order teaching and learning process can be achieved effectively and efficiently. This kind of terminology cannot be separated, the organization key is that technique caries out the method which is approach that is a set of correlative assumptions dealing with the nature of language and based upon. So, an approach means that the assumptions of language and language teaching under operating.

\section{English Text}

In this part discusses about definition of English text, the element of text, the part of text, and types of text.

Definition of English Text

Text is a piece of naturally occurring spoken, written, or signed discourse identified for purposes of analysis it is often a language unit with a definable communicative function, such as a conversation, a poster. A text or piece of discourse consists of more than one sentence and the sentence combine to form a meaningful. In this case, a text is set of discourse consist of group sentences, clauses, and paragraph to give meaning to user of language.

The text is the main written or printed part of book or page, contrasted with notes and illustration; furthermore text is the complex unit of language abstractly, furthermore. he states 
text is groups of worlds, phrases, clauses, and sentences in written and oral form.

The Element of Text

\section{1) Word}

The basic component in text is pattern of sentence and organizing of words in starting to write, the writer should know some techniques such as diction of word, and choosing words.

Using the figurative language, it is style and form of text.

The students have understood the way arranging the words to be right sentence, so they can write a short paragraph too. In this case, word is a sound or groups of sound that expresses a meaning and forms an independent unit of a language.

\section{2) Sentence}

A sentence is group of words that we use to communicate the ideas in writing or speaking. It is complete, independent unit of thought and consists of two main parts: a subject and predicate, the subject is word or words that name the person, thing, or place that a sentence is about. It is usually a noun or pronoun the prediction. It expresses an action or a state or being. A complement is word or words used to complete the meaning of the verb. (Muhammad, 1995).

\section{3) paragraph}

A paragraph is groups of sentences or related sentences that develop one main idea .The number of sentences are unimportant, however, the paragraph should be long enough to develop the main idea clearly. The following model contains all elements as topic sentences of a good paragraph as quoted form. (Oshima, 1981).

4) Grammar

Grammar is 1) an analysis of the structure of a language, either as encountered in a corpus of speech or writing (a performance grammar) or predictive of a speaking knowledge (a competence grammar). A contrast is often draw between descriptive grammar, which provides a precise account of actual usages, and a prescriptive grammar, which tries to establish rules for the correct used of language in society. 2) An analysis of the structural properties, which define human language (a universal grammar). 3) A level of structural organization, which can be studied independently of phonology and semantics."

Furthermore he states grammar is a systematic description of the ways in which, the words are used in a parcular language, which words bear to one another when they care, put together in sentences. Understanding of these relations requires some knowledge of the nature, the forms, and the history of words, but only so far as these bear on the uses of words in sentences The proper starting point of English grammar is the sentences. The discussion of words considered by them belong to the dictionary .The object of the study of grammar is to learn the uses of words in sentences, so that we may test the habits of speech, which we have already acquired, and make them perform to best models. We need English grammar or structure because without understanding English structure we will not know what the sentence means. Grammatical structure is the pattern of the arrangement of part of sentences. Structure means the pattern and the rule of sentences. Sentences structure should be mastered by the students in order to build their communicative skill.

Points out that sentence are the integrated part of language use. In other words, the knowledge of grammatical structure should be mastered by the students in order to be competent in communicative skill. In other part, Structure is taught deductively by presenting grammatical rules and the explanation followed by examples and drills.

5) Punctuation

Punctuation is a mark in writing sentences or paragraph. Many point concerning with punctuation are largely a matter of style, but there are certain principles that may serve as a guide.

The most important thing to remember about punctuations is its contribution to meaning. Punctuation affects the meaning of writing sentences. Without any punctuation in sentences, it may cause ambiguity, even it hard to decide what the sentences mean. Punctuation is not merely a set of mechanical rules but also can indicate relationship with sentences. Even though, decision about particular uses of punctuation is somewhat flexible, choices must be made. 


\section{The part of Text}

In text there are three parts of paragraph that have to be known or understood, because these parts construct as developer of a paragraph. These parts are topic sentence, supporting sentence, and concluding sentence. The paragraph is a basic unit of organization in writing in which a group of related sentence develop a main idea. It can be concluded that a paragraph a unit of organization that may give unified information.

\section{1) Topic sentence}

Topic sentence is complete sentence that contain a subject, a verb, and complement. It indicates the main idea of a paragraph.

A topic sentence has a particular function: to introduce the topic and controlling idea of a paragraph. Where the topic sentence should be placed in paragraph? Generally, because the topic sentence does introduce, it is a good idea to place it at or near the beginning of the paragraph. However, it depends on the kind of paragraph, the topic sentence may be placed near the middle or even at the end of the paragraph. sometimes neither the topic nor the controlling idea is explicitly ststed in one sentence, this does not mean, however, that is topic and controlling idea are implied, that is why, they are clearly suggested in the development of the paragraph. However it is usually a good idea to state topic sentence clearly but also to control development of the paragraph.

Topic sentence is a complete sentence, which contains a subject, a verb, and complement. It introduces the subject of a paragraph it indicates the main idea of paragraph. It indicates the main idea of paragraph and it is the most general statement in the paragraph. (Muhammad.1995).

2) supporting sentence

Supporting sentence develops the topic sentence by giving reasons. The supporting sentences they make up the rest of the paragraph and consist of two kinds; mayor supporting sentences and minor supporting sentences mayor supporting sentences which directly support the idea expressed in the topic sentences minor supporting sentences are sentences which directly support the mayor supporting sentences and at the same indirectly support the topic sentences. However, the main function of the supporting sentence is to provide the reader with evidence that idea expressed in the topic sentence is true, (Muhammad,1995).

Supporting sentence is group of sentences that develop or support a topic sentence. Supporting sentence make up the rest paragraph and consists of two kinds, mayor supporting sentence, and minor supporting sentence.

3) concluding sentence

A concluding sentence is not absolutely necessary, but it is often very helpful to the reader because it is signal at the end of the paragraph and because it remains him or her your important point. When the writer thinks that his writing have to be finished, he cannot finish her writing immediately. She/he needs a conclusion to end her/his work. In this case, the concluding sentence is much needed. A concluding sentence usually signal the end of the paragraph and it reminds us to the important point discussed in the paragraph it is not absolutely present, but it I helpful to readers because it is the emphasis of the point that has been explained in the paragraph. The concluding sentence indicates by the presence of the words or phrases, such as to sum up, and summary of the paragraph.

A concluding sentence serves there purposes namely (1)it signals at the end of the paragraph,(2) it summarizes the main point of the paragraph ,(3) it gives a final comment on your topic and leaves the readers with the most important ideas to think about. (Hamid syukri, 2003)

Concluding sentence repeats the main idea of the topic sentence in different word in other words, concluding sentence is the conclusion of the paragraph that concludes the idea of topic sentence.

\section{RESEARCH METHOD}

The success or the failure of the research depends on the design that was used, and in research activity design took a very important role in order to achieve the purpose of the research that was demand. So it was considered important to describe the methodology that was used in this study.

The method used in this study was descriptive research. It explained about 
students' comprehension in analyzing English text.

Population of the study

According to Arikunto (2002) population is the sum of people, which have the same characteristics. In this research, the population of the study was all of the tenth year students of MA Darul Furqan NW Mengkuru that consisted of 268 students which were divided into six classes as follows:

\begin{tabular}{|c|c|c|}
\hline No & Classes & $\begin{array}{c}\text { Sum of } \\
\text { Population }\end{array}$ \\
\hline 1 & XI & 43 \\
\hline 2 & XII & 43 \\
\hline 3 & XIII & 43 \\
\hline 4 & XIV & 43 \\
\hline 5 & XV & 43 \\
\hline 6 & XVI & 43 \\
\hline \multicolumn{2}{|c|}{ TOTAL } & 268 \\
\hline
\end{tabular}

Sample of the Study

According to Arikunto (2002) sample is a part of representative of population that are examined or investigated. In determining the sample of the study, the writer took what is suggested by Arikunto that, if the population is less than 100 , the whole numbers of population must be taken. But, if it is more than 100 , it can be taken between $10-15 \%, 20$ $25 \%$.So,the writer took $11 \%$ or 30 students from the whole population as the sample of the study. In determining the sample, the writer used random sampling technique, by using lottery technique. In this case, the writer put name of population in a car or glass then the writer took 30 students by using lottery as the sample of the study.

Instruments of the Study

In collecting data of this study, the writer used test as the instrument in observing of data collection. Arikunto (2002) says that teacher makes test which is arranged by the teacher with certain procedure, this kind of test is not tested yet its characters and its benefit is also not known yet.

In this study, the writer conducted the kind of activities such as analyzing English text; they were descriptive text, recount text, repot text and procedure text.
The fifth genre of English texts was made as instrument because in the study, the researcher investigated and looked for the students' comprehension in analyzing English texts. therefore, thirty of students as sample of the study was asked to analyze an English text. The score was given to each number of items with determination: the criteria for scoring students 'answer as follows:

In collecting data of this study, the researcher used a test namely subjective test in the form of test essay consisted 5 items.

\begin{tabular}{|l|c|c|c|c|c|}
\hline \multirow{2}{*}{ Items } & \multicolumn{5}{|c|}{ Point of each text } \\
\cline { 2 - 6 } & $\begin{array}{c}\text { desc } \\
\text { ripti } \\
\text { ve }\end{array}$ & $\begin{array}{c}\text { Na } \\
\text { rrat } \\
\text { ive }\end{array}$ & $\begin{array}{c}\text { Re } \\
\text { cou } \\
\text { nt }\end{array}$ & $\begin{array}{c}\text { Rep } \\
\text { ort }\end{array}$ & $\begin{array}{c}\text { Proce } \\
\text { dure }\end{array}$ \\
\hline $\begin{array}{l}\text { Types of } \\
\text { text }\end{array}$ & 1.5 & 1.5 & 1.5 & 1.5 & 1.5 \\
\hline $\begin{array}{l}\text { Purposes of } \\
\text { text }\end{array}$ & 1.5 & 1.5 & 1.5 & 1.5 & 1.5 \\
\hline $\begin{array}{l}\text { Social } \\
\text { function }\end{array}$ & 5 & 5 & 5 & 5 & 5 \\
\hline $\begin{array}{l}\text { Language } \\
\text { features }\end{array}$ & 2 & 2 & 2 & 2 & 2 \\
\hline
\end{tabular}

Notes:

1. Item number 1 and 2 were given point 1.5 because they have only one element of short correct answer;

2. Item number 3 was given point 5 because it has only more than two elements of correct answer;

3 . Item number 4 was given point 2 because it has only two elements of short correct answer;

3.4 technique of Data Collection

In collecting data, there are some phase, that was used in this study, they are:

1. Giving a short explanation about technique and systematic in analyzing English texts;

2. Asking the sample to analyze English texts that were analyzed by the sample;

3. Collecting the English texts that were analyzed by the sample;

4. Analyzing the students' comprehension in analyzing an English text.

Technique of Data analysis

Technique of data analysis used in this research was descriptive statistics. it was used to determine the data into high, average, and low categories .For the purpose, the following formula was used: 
$\mathrm{Mi}+1 \mathrm{SDi}$ to $\mathrm{Mi}+3 \mathrm{SDi}=$ high

$\mathrm{Mi}+1 \mathrm{SDi}<\mathrm{Mi}+1 \mathrm{SDi}=$ average

$\mathrm{Mi}+3 \mathrm{SD}<\mathrm{Mi}-1 \mathrm{SDi}=$ low

After the data were derived directly: this part discusses about some procedures of data analysis suggested by the experts who involved three steps such as identifying of the students' comprehension in analyzing English texts, and finding out the percentages.

Based on above procedures, first, the researcher identified the students, comprehension by the students. Second, the researcher described and classified the students' comprehension in analyzing English text based on a certain categories and the third, the researcher found out the sources of students' comprehension in analyzing English text in order that the researcher was able to solve the problem based on the students' comprehension in analyzing English texts.

Briefly, the researcher used some steps:

1. Giving the score toward the students' answer

2. Counting the quantity of the students' score in comprehending an English text

3. Identifying and describing the learners' ability

4. Finding the score of the learners' ability. To obtain the information concerned to the students' comprehension in analyzing an English text, this study determines a table of percentage scale and qualification as follows.

\begin{tabular}{|c|c|c|}
\hline No & Percentage & Qualification \\
\hline 1 & $85 \%-100 \%$ & Very High \\
\hline 2 & $75 \%-84 \%$ & High \\
\hline 3 & $60 \%-74 \%$ & Sufficient \\
\hline 4 & $40 \%-59 \%$ & Low \\
\hline 5 & $0 \%-39 \%$ & Very low \\
\hline
\end{tabular}

\section{RESULT AND DISCUSSION}

After gathering the data, the researcher gave three criteria for the ability of the students' comprehension in analyzing English text; the criteria are high, average, and low; for the percentage of successes of students' comprehension in analyzing English text, the researcher gave five criteria; the criteria are very high, high, sufficient, low, and very low.

After the scores were classified for the students' comprehension in analyzing English text, the writer found 4 students who got very high score. It means that there were $13.33 \%$ of them were categorized very high level. Furthermore, there were students who got high level; it means that were $13.33 \%$ of students who were categorized high level. There were7 students who got sufficient level; it means that there were $23.33 \%$ of students who were categorized high level, and there were 15 students who got low level; it means that there were $50 \%$ of students who were categorized low level; Moreover, there were none of students who got very low criteria.

On the order hand, for the percentage of success of students' comprehension in analyzing English text, the write found 12 students who got high criteria, it means that $40 \%$ of students got high criteria, it means that $60 \%$ of students got high criteria, Furthermore, there were none students who got low criteria, it means that there were $0 \%$ of them were categorized the low criteria.

After the scores were classified, the researcher calculated the mean score of the entire students and it was find out that the means score of the students was 31.35. It means that the students' comprehension in analyzing English text was average category (it was based on the criteria used).

Discussion

In this sub heading, the writer presents about the answer of the problems, which have been stated on the statement of this study. The problems are to what extent is the statements' comprehension in analyzing English text for the tenth year students of MA Darul Furqan NW Mengkuru and to what extent is the percentage of students' comprehension in analyzing English text for the tenth year students of $M A$ Darul Furqan NW Mengkuru.

\section{The Students' Comprehension in Analyzing English text}

The students' comprehension in analyzing English text for the tenth year students of MA Darul Furqan NW Mengkuru in the school year 2009/20010 was calculated. To investigate the result of the students' comprehension in analyzing English text, the writer used statistic descriptive for the categories in which it consists of the Ideal Maximum score was 55 and ideal minimum scores was 0.The ideal 
Mean scores (Mi) gained was 25 and ideal Standard Deviation (SDi) was 833.

The categories gained after the calculation into the staderd categories are as follws:

$\mathrm{Mi}+1 \mathrm{Sdi}$ to $\mathrm{Mi}+3 \mathrm{Sdi}=$ high

$25+1(8.33)$ to $25+3(8.33)$

$25+8.33$ to $25+24.99$

33.33 to 49.99

Mi - 1 Sdi to $<M I+1$ Sdi =Average

$25-1(8.33)$ to $<25+1(8.33)$

$25-8.33$ to $<25+8.33$

16.67 to $<33.33$

Mi - 3 Sdi to $<$ MI - 1 Sdi = low

$25-3(8.33)$ to $<25-1(8.33)$

$25-24.99$ to $<25-13.33$

0.01 to $<16.67$

Based on the above data analysis, the students' comprehension in analyzing English text were in high level. It was proved by the means scores of the students that were 31.35. While 31.35 is belong to the average level.

The Percentage of Success of the Students' Comprehension in Analyzing English Text

The percentage of success of students' comprehension in analyzing English text for the tenth year students of MA Darul Furqan NW Mengkuru was calculated.

After the scores were classified for the students' comprehension in analyzing English text, the researcher found 4 students who got very high score. It means that there were $13.33 \%$ of them were categorized very high level. Furthermore, there were 4 students who got high level; it means that there were $13.33 \%$ of students who were categorized high level. There were 7 students who got sufficient level; it means that there were $23.33 \%$ of students who categorized high level; and there were 15 students who got low level; it means that there were $50 \%$ of students who were categorized low level, Moreover, there were none of students who got very low criteria.

\section{CONCLUSION}

The Researcher could draw several conclusions;

The students' comprehension in analyzing English text for the tenth year students of MA Darul Furqan NW Mengkuru are in average level. It can be seen from the mean score of the students that is 31.35 in which this number belongs average level. The percentages of successes of students' comprehension in analyzing English text for the tenth year students of MA Darul Furqan NW Mengkuru are low. After the scores were classified for the students' comprehension in analyzing English text, the researcher found 4 students who got very high score. It means that there were $13.33 \%$ of them were categorized very high level. Furthermore, there were 4 students who got high level; it means that there were $13.33 \%$ of students who were categorized high level. There were7 students who got sufficient level; it means that there were $23.33 \%$ of students who were categorized high level, and there were 15 students who got low level; it means that there were $50 \%$ of students who were categorized low level, moreover, there were none of students who got very.

\section{REFERENCES}

Arikunto., Suharsimi. 2002. Prosedur Penelitian: suatu Pendekatan Praktek. Edisi Revisi. IV. Jakarta: Rineka Cipta

Brown, H.D, 2003. Language Assessments: Principle and Class Room Practice. San Francisco state University. Longman.

Cahyono, bambang Yudi. 1997. Pengajaran Bahasa Inggris: Tehnik, Strategi dan Hasil Penelitian. Malang: IKIP Malang

Depdiknas. 2005. Bahan Pelatihan terintagrasi pembelajaran teks bahasa inggris: Jakarta. Departmen pendidikan dasar dan menengah.

Depdiknas. 2005. Bahan Pelatihan terintagrasi berbasis berkompetisi: Jakarta. Departmen pendidikan dasar dan menengah.

Hamid syukri. 2003. Writing easy for academic writing. Mataram university press.

Hamid syukri. 2003. Teaching English Paragraph. Mataram university press.

Muhammad, AM. 1995. Paragraph Writing. Handout. STKIP Hamzanwadi Selong. Hamzanwadi Selong. Unpublish.

Oshima, Alice. 1981. Writing Academic a Writing and sentence Stucture Workbook for International Students. California: addition Wesley Publishing co. 